\title{
АНАЛИЗ ОТХОДОВ ЛИТЕЙНОГО ПРОИЗВОДСТВА, СОДЕРЖАЩИХ ПЛАСТИФИКАТОР НА ОСНОВЕ МЕЛАМИНОФОРМАЛЬДЕГИДНОЙ СМОЛЫ, МЕТОДОМ ИК-СПЕКТРОСКОПИИ
}

Рахимова О.В., Захаров И.С.

Санкт-Петербургский государственный электротехнический университет «ЛЭТИ» им. В.И.Ульянова (Ленина), Санкт-Петербург, Россия

olga-18061963@yandex.ru

DOI: 10.26902/ASFE-11_188

Цель настоящей работы заключалась в оценке экологической опасности отходов литейного производства, представляющих собой отработанную формовочную массу, содержащую в качестве связующего материала один из популярных в литейном производстве пластификатор МФ на основе меламиноформальдегидной смолы, в состав которой входят меламин $\left(\mathrm{C}_{3} \mathrm{H}_{6} \mathrm{~N}_{6}\right)$, формальдегид $\left(\mathrm{CH}_{2} \mathrm{O}\right)$, бутанол $\left(\mathrm{C}_{4} \mathrm{H}_{9} \mathrm{OH}\right)$, а также остатки аммиака $\left(\mathrm{NH}_{3}\right)$, который используется при её синтезе.

Исследования были выполнены методом нарушенного полного внутреннего отражения (НПВО) на ИК Фурье-спектрометре Vertex 70 фирмы Bruker и отражательной приставке MНПВО фирмы Pike Technologie. В качестве элементов МНПВО использовали кристаллы KRS-5 с углом падения излучения на объект $\theta=45^{\circ}$. Результаты исследований представлены на рис. 1.

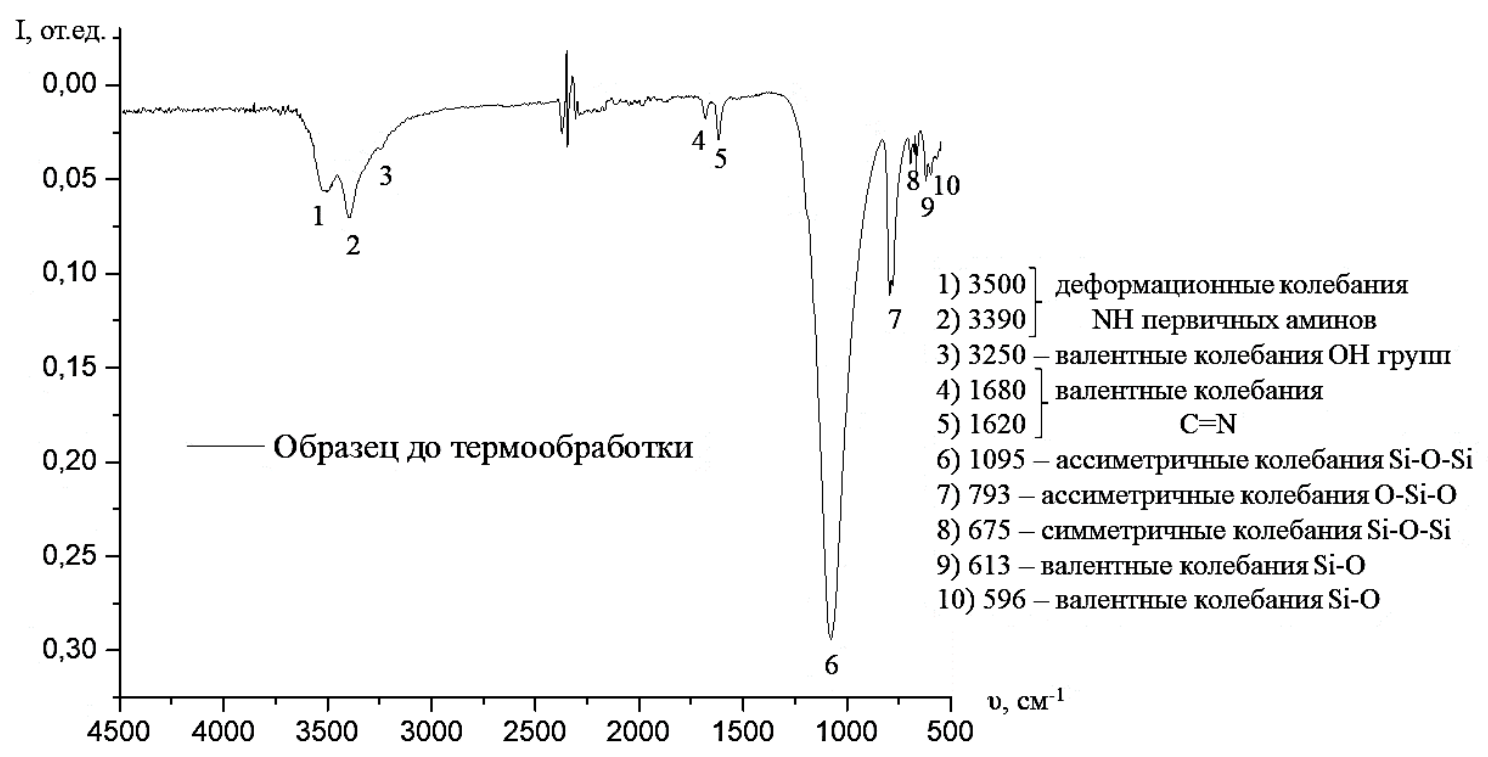

Рис. 1. Результаты ИК-спектроскопии в режиме МНПВО для образца без термообработки

Характеристические полосы поглощения 4 и 5 указывают на наличие азометиновых групп, содержащихся в основаниях Шиффа - N-замещенных алифатических иминах, или на присутствие в образце изоцианатов $-\mathrm{N}=\mathrm{C}=\mathrm{O}$. Алифатические имины хорошо гидролизуются с образованием карбонильных соединений и аминов. Амины относятся ко II классу опасности, изоцианаты - к I классу опасности [1], что необходимо учитывать при захоронении и утилизации отходов литейного производства, содержащих пластификатор на основе меламиноформальдегидной смолы.

\section{Список литературы}

1. ГОСТ 12.1.007-76 Система стандартов безопасности труда (ССБТ). Вредные вещества. Классификация и общие требования безопасности (с Изменениями № 1, 2). 